This is an author produced version of a paper published in Scandinavian Journal of Forest Research.

This paper has been peer-reviewed but may not include the final publisher proof-corrections or pagination.

Citation for the published paper:

Fries, Anders; Elfving, Björn; Ukrainetz, Nicholas. (2017) Growth and survival of lodgepole pine and Scots pine after 25 years in a reciprocal transplant experiment in Canada and Sweden. Scandinavian Journal of Forest Research. Volume: 32, Number: 4, pp 287-296.

http://dx.doi.org/10.1080/02827581.2016.1221990.

Access to the published version may require journal subscription. Published with permission from: Taylor \& Francis Group.

Standard set statement from the publisher:

This is an Accepted Manuscript of an article published by Taylor \& Francis in Scandinavian Journal of Forest Research on 12 aug 2016, available online: http://www.tandfonline.com/ 10.1080/02827581.2016.1221990

Epsilon Open Archive http://epsilon.slu.se 


\title{
Growth and survival of lodgepole pine and Scots pine after 25 years in a reciprocal transplant experiment in Canada and Sweden
}

\author{
Anders Fries $^{\mathrm{a}}$, Björn Elfving $^{\mathrm{b}}$ and Nicholas K. Ukrainetz ${ }^{\mathrm{c}}$ \\ ${ }^{\mathrm{a}}$ Department of Forest Genetics and Plant Physiology, Umeå Plant Science Centre, Swedish \\ University of Agricultural Sciences, Umeå, Sweden \\ ${ }^{b}$ Department of Forest Ecology and Management, Swedish University of Agricultural Sciences, \\ Umeå, Sweden
}

'Ministry of Forests, Lands and Natural Resource Operations, Tree Improvement Branch, Tree Seed Centre, Surrey, BC, Canada

CONTACT Anders Fries anders.fries@slu.se Department of Forest Genetics and Plant Physiology, Umeå Plant Science Centre, Swedish University of Agricultural Sciences, Umeå SE-90183, Sweden

(Received 20 February 2015; final version received 04 August 2016)

\begin{abstract}
Lodgepole pine is native to western North America, but it is also planted as a fast-growing alternative to Scots pine in Sweden. The production of these two species, when grown as native and as exotic species, was compared in a transcontinental two-species provenance experiment. The tests were planted in 1986 on five sites in northwestern Canada and two sites in Sweden, and included full-sib families, half-sib families, seed orchard collections and natural stand seed collections of both species. After 25 years, lodgepole pine produced $48 \%$ more volume $\left(\mathrm{m}^{3} \mathrm{ha}^{-1}\right)$ and had $27 \%$ higher survival than Scots pine at one Swedish site, and had similar volume production and survival at a second. In the five Canadian sites, Scots pine produced on average $22 \%$ more volume than lodgepole pine. The variation between sites was, however, large. This higher volume of Scots pine in Canada could be due to higher survival (+28\%) and less frequent damage; but higher top height for lodgepole pine in Canada indicated higher potential productivity. The results indicate that an exotic species may produce more than the native species, possibly thanks to higher survival, but it is also possible to increase production with successful population selection of the native species.
\end{abstract}

KEYWORDS: Species interaction; exotic species; productivity; provenance transfer; competition; genetic correlation; stem damage 


\section{Introduction}

Introduced species have long been used in forestry to enhance productivity (Tigerstedt 1993), but few studies have adequately tested the actual effects of the introduction relative to native species. The realized niche of a species is strongly affected by its evolved tolerance to climate and pests, but when grown as an exotic species, it may flourish in the new environment, thanks to less pressure from pests and pathogens (Tigerstedt 1993). There are many examples of planned introductions of tree species that grow and perform well as exotics (Wang et al. 2006a; Cubbage et al. 2014; Verhaegen et al. 2014). One example where, in addition, the productivity is much lower in the natural range is the introduction of Monterey pine (Pinus radiata D. Don) to large areas in Australia, New Zealand, Chile and Africa, where it makes a very strong contribution to the forest industry (Piirto \& Valkonen 2005).

Another example of an introduction of a tree species for use in forestry is the planting of the interior variety of lodgepole pine (Pinus contorta Dougl. ex Loud. var. latifolia Engelm.), native to western North America, in northern and central Sweden. Observations from small plantations of lodgepole pine in Sweden and Finland from between 1910 and 1930 indicated that this exotic species could be more productive than the native Scots pine (Pinus sylvestris L.) (Elfving et al. 2001). In the 1960s, several provenance tests were established in Sweden to determine the most productive and welladapted provenances from North America (Karlman 1986; Lindgren et al. 1988; Rosvall et al. 1998). Since 1970, more than 600000 ha in northern and central Sweden have been planted with lodgepole pine (Skogsstyrelsen 2013). Around 130 field experiments that have been running for between 15 and 64 years indicate that it is on average ca. $36 \%$ more productive than Scots pine (Elfving \& Norgren 1993; Elfving et al. 2001), probably because it has larger needle biomass at a given stem volume (Elfving et al., unpublished data) and larger needle area at a given stem volume (Norgren 1996). The risks associated with introducing the species to Sweden have been thoroughly reviewed by Karlman (1981, 2001).

As far as we know, there are no published, systematic cross-validations of main tree species, comparing the development in the home range with that under exotic conditions. To address this, we made use of a transcontinental reciprocal transplant experiment which was established to compare the productivity, survival rates and damage by pests and pathogens of Scots pine and lodgepole pine at five sites in western Canada and two sites in Sweden (A Joint Swedish - Canadian 1987; Lindgren \& Lindgren 1990). The experiment was established in 1986 and included full-sib and half-sib families from the two species, together with seed-lots from collections in natural stands for reforestation (operational seed-lots). Test sites were chosen to represent a range of biotic and abiotic environments in western Canada and Sweden. The experiment was intended to quantify the benefits of using introduced lodgepole pine in Sweden and Scots pine in Canada, and to assess the potential spread of pests, pathogens and insects between the species. Early results from the Canadian test sites of this experiment have been published by Lindgren and Lindgren (1990), Van der Kamp et al. (1995) and Karlman et al. (1997) and further discussed by Karlman (2001). The average survival rates seven years after planting were $94 \%$ for lodgepole pine and $95 \%$ for Scots pine, with mean heights of about 1.70 and $1.45 \mathrm{~m}$, respectively (Karlman et al. 1997). 
The so-called enemy release hypothesis (Keane \& Crawley 2002; Mitchell \& Power2003) implies that a species can be more successful when used as an exotic species compared to being a native species, since in the new environment it does not meet the threats (pests and pathogens) that have evolved during its existence in its native environment. One effect of this could be higher production (Keane \& Crawley 2002). The opposite may also occur. A new pathogen or insect may seriously attack the exotic species so it produces considerably less in its new environment (Garbelotto \& Pautasso 2012). Another explanation for better success is that the biota in the new environment suits the introduced species better than where it is native. For lodgepole pine, for instance, Gundale et al. (2014) showed that the Swedish soil provides better biota than the Canadian soil, and Mclntosh et al. (2012) found that the nitrogen availability was better in the Swedish soil than in the Canadian since the latter had higher net nitrogen immobilization. With this study we want to compare the production of lodgepole pine and Scots pine when growing as native species and as exotic species. The results are discussed in the light of the "enemy release hypothesis" and possible differences in soil conditions between Sweden and Canada. The occurrence of diseases and insects in this material will be reported in a concurrent article, and the objectives of this work were (1) to compare the productivity after 25 years in the field between Scots pine and lodgepole pine when grown as native and exotic species in Canada and Sweden, (2) to provide possible reasons for the growth differences on the two continents, (3) to evaluate differences between provenances of both species and (4) to evaluate the phenotypic stability over environmental gradients of the species.

\section{Materials and methods}

\section{Plant material}

Full-sib families, half-sib families, seed orchard seed-lots and operational seed-lots of lodgepole pine and Scots pine were used (Table 1(a,b)). Due to the young age of the lodgepole pine and Scots pine seed orchards resulting in reduced flower production, it was not possible to create full-sib families for all parents and populations. Consequently, also half-sib and polycross families had to be included, together with operational seed-lots. The lodgepole pine full-sib families were created in four seed orchards in Sweden (Norrberge, Sör Nedansjö, Lögdö and Galtström) belonging to SCA (Svenska Cellulosa Aktiebolaget). The orchards were composed of phenotypically selected but untested parent trees originating from British Columbia and Yukon, and a total of 42 parents were used to create 32 full-sib families. Seed for lodgepole pine half-sib families was collected from selected parent trees in close proximity to the test sites. Seven operational lodgepole pine wild-stand seed collections were also included. The Scots pine full-sib families were created in several Swedish seed orchards by crossing among phenotypically selected but untested parent trees. Several half-sib Scots pine families were created by applying a pollen mix to parent trees in two seed orchards in Sweden (Skogsgård and Klocke, in which three and 20 pollen donors were used, respectively). Half-sib and full-sib families were grouped into provenances based on the location of origin of the parent trees (Figure 1). 


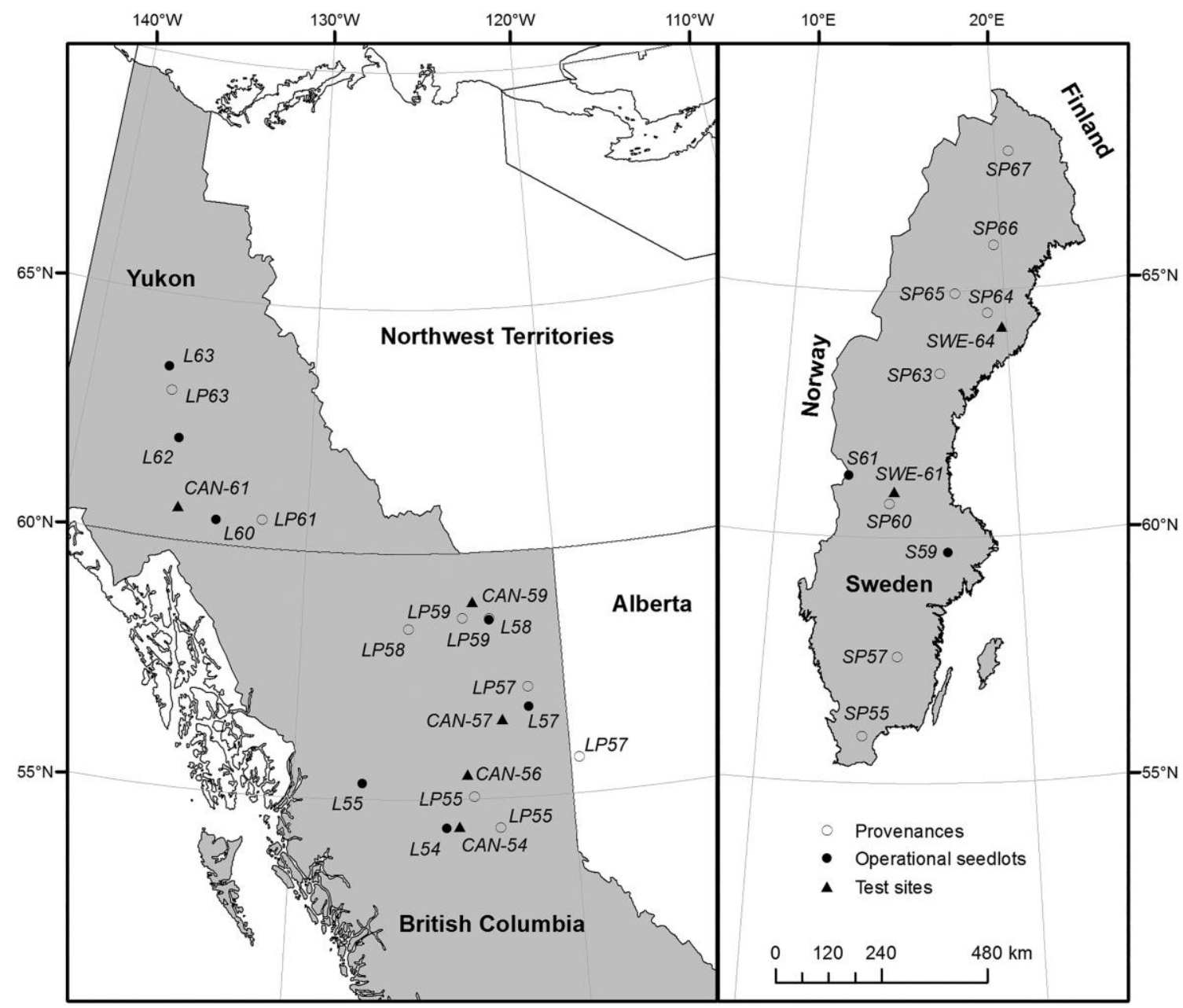

Figure 1. Locations of the test sites, and origins of provenances and operational control seed-lots in Canada and Sweden. The provenances and operational control seed-lots were collected from the area surrounding the point source located on the map. See Table 1 for definitions of the abbreviations. 
Table 1. Origins of (a) lodgepole pine (LP or L) and (b) Scots pine (SP or S) seed used in the reciprocal transplant experiment.

\begin{tabular}{|c|c|c|c|c|c|c|}
\hline Origin & Provenance & $\begin{array}{l}\text { Family } \\
\text { structure }\end{array}$ & $\begin{array}{c}\text { No. of } \\
\text { families }\end{array}$ & $\begin{array}{l}\text { Latitude } \\
\left({ }^{\circ} \mathrm{N}\right)\end{array}$ & $\begin{array}{l}\text { Longitude } \\
\text { (Can: }{ }^{\circ} \mathrm{W} \text {, Swe: } \\
\left.{ }^{\circ} \mathrm{E}\right)\end{array}$ & $\begin{array}{l}\text { Elevation } \\
\text { (m) }\end{array}$ \\
\hline $\begin{array}{l}\text { Southern } \\
\text { group }\end{array}$ & LP58 & Full sibs & 16 & $\begin{array}{c}56.28- \\
59.78\end{array}$ & $122.74-129.57$ & $618-1020$ \\
\hline $\begin{array}{l}\text { Central } \\
\text { group }\end{array}$ & LP61 & Full sibs & 8 & $\begin{array}{c}60.75- \\
60.89\end{array}$ & $129.52-134.80$ & 579-926 \\
\hline $\begin{array}{l}\text { Northern } \\
\text { group }\end{array}$ & LP63 & Full sibs & 8 & $\begin{array}{c}62.22- \\
63.62\end{array}$ & 134.90-136.67 & $552-1091$ \\
\hline $\begin{array}{l}\text { Summit } \\
\text { Lake }\end{array}$ & P55 & Half sihc & 4 & 54.40 & 122.62 & 813 \\
\hline Philip Creek & & & 4 & 55.05 & 123.50 & 1020 \\
\hline Saddle Hills & \multirow{2}{*}{ LP57 } & \multirow{2}{*}{ Half sibs } & 4 & 55.73 & 119.67 & 825 \\
\hline $\begin{array}{l}\text { Beatton } \\
\text { River }\end{array}$ & & & 4 & 57.23 & 121.37 & 1010 \\
\hline Fort Nelson & \multirow[b]{2}{*}{ LP59 } & \multirow{2}{*}{ Half sibs } & 2 & 58.65 & 122.70 & 495 \\
\hline $\begin{array}{l}\text { Steamboat } \\
\text { Mtn. }\end{array}$ & & & 2 & 58.67 & 123.75 & 630 \\
\hline $\begin{array}{l}\text { Fort St } \\
\text { James }\end{array}$ & $\mathrm{L} 54^{\mathrm{a}}$ & & Unknown & 54.42 & 124.50 & 805 \\
\hline Hazelton & $\mathrm{L} 55^{\mathrm{a}}$ & & Unknown & 55.33 & 127.50 & 600 \\
\hline $\begin{array}{l}\text { Beatton } \\
\text { River }\end{array}$ & $\mathrm{L} 57^{\mathrm{a}}$ & & Unknown & 56.83 & 121.37 & 800 \\
\hline Fort Nelson & $\mathrm{L} 58^{\mathrm{a}}$ & & Unknown & 58.63 & 122.70 & 495 \\
\hline Squanga & $\mathrm{L} 60^{\mathrm{a}}$ & & Unknown & 60.50 & 133.75 & 792 \\
\hline Carmacks & $\mathrm{L} 2^{\mathrm{a}}$ & & Unknown & 62.07 & 135.70 & 569 \\
\hline Rusty Creek & $\mathrm{L} 63^{\mathrm{a}}$ & & Unknown & 63.50 & 136.57 & 760 \\
\hline
\end{tabular}




\begin{tabular}{|c|c|c|c|c|c|c|}
\hline \multicolumn{7}{|c|}{ (b) } \\
\hline Origin & Provenance & $\begin{array}{l}\text { Family } \\
\text { structure }\end{array}$ & $\begin{array}{c}\text { No. of } \\
\text { families }\end{array}$ & $\begin{array}{l}\text { Latitude } \\
\qquad\left({ }^{\circ} \mathrm{N}\right)\end{array}$ & $\begin{array}{l}\text { Longitude } \\
\text { (Can: }{ }^{\circ} \mathrm{W}, \\
\left.\text { Swe: }{ }^{\circ} \mathrm{E}\right)\end{array}$ & $\begin{array}{l}\text { Elevation } \\
\text { (m) }\end{array}$ \\
\hline Haradstorp & SP55 & Full sibs & 8 & $\begin{array}{l}55.96- \\
56.22^{\circ}\end{array}$ & $13.34-14.28$ & $15-100$ \\
\hline $\begin{array}{l}\text { Reference } \\
\text { cross }\end{array}$ & SP60 & Full sibs & 1 & 60.68 & 14.68 & 280 \\
\hline Domsjöänget & SP63 & Full sibs & 11 & $\begin{array}{c}62.49- \\
65.33\end{array}$ & 15.54-19.96 & $185-360$ \\
\hline Brån & SP64 & Full sibs & 4 & $\begin{array}{c}63.80- \\
64.81\end{array}$ & 19.96-20.14 & 90-355 \\
\hline Östteg & SP65 & Full sibs & 9 & $\begin{array}{c}64.49- \\
64.85\end{array}$ & $17.51-19.61$ & $220-435$ \\
\hline Skatan & SP66 & Full sibs & 8 & $\begin{array}{c}65.02- \\
67.42\end{array}$ & $18.20-21.30$ & 265-390 \\
\hline Skogsgård & SP57 & $\begin{array}{l}\text { Half sibs } \\
\text { and full } \\
\text { sibs }^{b}\end{array}$ & 8 & $\begin{array}{c}57.42- \\
57.69\end{array}$ & $14.74-15.62$ & $140-184$ \\
\hline Klocke & SP67 & $\begin{array}{l}\text { Half sibs } \\
\text { and full } \\
\text { sibs }^{b}\end{array}$ & 8 & $\begin{array}{c}67.16- \\
67.57\end{array}$ & 19.94-21.56 & $363-438$ \\
\hline Långtora & S59 ${ }^{c}$ & & Unknown & 59.65 & 18.27 & 103 \\
\hline Askerud & $S 61^{\mathrm{C}}$ & & Unknown & 60.78 & 13.01 & 364 \\
\hline
\end{tabular}

\footnotetext{
${ }^{\text {a } L o c a l ~ l o d g e p o l e ~ p i n e ~ c o n t r o l ~ s e e d-l o t s ~ i n ~ C a n a d i a n ~ t e s t ~ s i t e s, ~ n a m e d ~ L P L ~ i n ~ T a b l e s ~} 4$ and 5, and in the text. ${ }^{b}$ Orchard polycrosses creating a mix of half-sib and full-sib families with 3 and 20 pollen parents, respectively. ${ }^{\mathrm{c} B u l k}$ orchard collection with no family structure. There were 36 seed donors at Långtora and 43 at Askerud, and the pollen donors were either the clones in the orchard, or trees from outside the orchard.
}

Seedlings for the Canadian sites were grown in 1985 at the Balco Nursery (now Tolko Nursery) situated in Kamloops (latitude $50.6^{\circ} \mathrm{N}$ ), British Columbia, and for the Swedish sites at the Faculty of Forestry nursery at the Swedish University of Agricultural Science in Umeå (latitude $63.8^{\circ} \mathrm{N}$ ). In Sweden, seedlings were grown indoors until early July and material from southern latitudes was treated with prolonged nights after July 22. 


\section{Planting and test sites}

Seedlings were planted in the spring of 1986 on five test sites in western Canada (four in British Columbia and one in Yukon; site codes CAN-54, -56, -57, -59 and -61) and two test sites in Sweden (site codes SWE-61 and -64) (Figure 1; Table 2). The test sites were selected to represent a wide range of geographic and climatic conditions. The Renberget site (SWE-64) was fenced to protect seedlings from moose (Alces alces) and reindeer (Rangifer tarandus), and the Fort St John site was fenced against cattle. At Garsås (SWE-61), both Scots pine and lodgepole pine were heavily damaged by pine weevil (Hylobius abietis) at a young age and by moose at an older age. Thus, based on the criterion that the plots should have more than 20 of 64 living trees to be selected for evaluation, only $45 \%$ of the plots were evaluated.

Table 2. Field tests included in the reciprocal transplant experiment with LP and SP.

\begin{tabular}{|c|c|c|c|c|c|}
\hline Location & $\begin{array}{l}\text { Site } \\
\text { code }\end{array}$ & $\begin{array}{l}\text { Latitude } \\
\left({ }^{\circ} \mathrm{N}\right)\end{array}$ & $\begin{array}{l}\text { Longitude(Can: } \\
\left.\text { 'W, Swe: }{ }^{\circ} \mathrm{E}\right)\end{array}$ & Elevation(m) & Soil type \\
\hline $\begin{array}{l}\text { Fort St } \\
\text { James }\end{array}$ & $\begin{array}{l}\text { CAN- } \\
54\end{array}$ & 54.45 & 124.05 & 855 & $\begin{array}{l}\text { Sandy, some gravel } \\
\text { and silt. } 1-3 \mathrm{~cm} \text { organic } \\
\text { layer }\end{array}$ \\
\hline Mackenzie & $\begin{array}{l}\text { CAN- } \\
56\end{array}$ & 55.50 & 123.72 & 680 & $\begin{array}{l}\text { Medium to coarse } \\
\text { sand, some gravel. Ca. } \\
1 \mathrm{~cm} \text { organic layer }\end{array}$ \\
\hline $\begin{array}{l}\text { Fort St } \\
\text { John }\end{array}$ & $\begin{array}{l}\text { CAN- } \\
57\end{array}$ & 56.60 & 122.37 & 800 & $\begin{array}{l}\text { Medium to coarse sand } \\
\text { with gravel. Partly thick } \\
\text { organic layer }\end{array}$ \\
\hline Fort Nelson & $\begin{array}{l}\text { CAN- } \\
59\end{array}$ & 59.00 & 123.33 & 600 & Silt clay (rather heavy) \\
\hline Whitehorse & $\begin{array}{c}\text { CAN- } \\
61\end{array}$ & 60.68 & 135.37 & 660 & $\begin{array}{l}\text { Silt soil, medium to fine } \\
\text { sand. Little or no } \\
\text { organic matter }\end{array}$ \\
\hline Garsås & $\begin{array}{c}\text { SWE- } \\
61\end{array}$ & 60.93 & 14.88 & 205 & $\begin{array}{l}\text { Sandy till. Thin organic } \\
\text { layer }\end{array}$ \\
\hline Renberget & $\begin{array}{l}\text { SWE- } \\
64\end{array}$ & 64.25 & 19.80 & 225 & $\begin{array}{l}\text { Sandy till/fine sand. } \\
\text { Some stony ground }\end{array}$ \\
\hline
\end{tabular}




\section{Experimental design}

Each site was established using a randomized complete block design with five blocks per site. At every site except SWE-61, blocks $1-4$ were composed of $8 \times 8$ tree square plots with separate species and provenances. The number of plots (treatments) per block varied between 9 and 11. Block 5 was composed of single tree plots with mixed species, provenances and families. At SWE$61,4 \times 16$ tree plots were used, instead of $8 \times 8$ tree square plots, in blocks $1-4$. A $2 \mathrm{~m} \times 2 \mathrm{~m}$ square spacing was used. The number of individuals per full-sib or half-sib family at each site was unbalanced and ranged from 2 to 61, with most families represented by between 8 and 40 individuals per site. Families were planted at random within provenance plots. In general, three rows of surround trees were planted around each trial.

\section{Measurements}

The measurements were made in 2010, when active growth was nearly complete (end of June and beginning of July) in Canada and after completion of seasonal growth (August and October to December) in Sweden. The status of each tree was recorded, along with diameter at breast height ( $\mathrm{DBH}$, one measure to the nearest half centimeter at $1.3 \mathrm{~m}$ above the ground) in blocks $1-4$ for sites in Canada and all five blocks for the two Swedish sites. At the Canadian sites, the largest stem of double stems was measured, so productivity was slightly underestimated. Tree height was measured to the nearest decimeter of every 10th tree from each provenance $(8 \times 8$ tree plot $)$ using a vertex hypsometer and the average of three measurements per tree was recorded (HT). When a tree that was preselected for height growth measurement had abnormal form (e.g. a fork or broken top) the closest representative tree was selected in its place. There was substantial mortality caused by mountain pine beetle at Fort St James and Mackenzie (CAN-54 and CAN-56, respectively). We preferred to estimate total productivity without considering this extreme event, so both living trees and trees that had recently died (1-3 years before assessment) were assessed and measured for diameter.

\section{Calculations of stem volume and top height}

Individual tree stem volumes including bark over stump height (1\% of tree height) were calculated for all trees for which height measurements were taken. For lodgepole pine and Scots pine trees with $>5$ cm DBH, volume functions presented by Eriksson (1973) and Brandel (1990) were used, respectively, while functions presented by Andersson (1954) were used for trees with smaller diameters.

Secondary volume functions were created for each species and site as a function of diameter (DBH) using the following equation:

$\ln (\mathrm{VOL})=b_{0}+b_{1} \times \ln (\mathrm{DBH}+1)+b_{2} \times \ln (\mathrm{DBH}+1)^{4}$,

where $\mathrm{VOL}=$ single tree stem volume according to the volume function and $b_{0}-b_{2}=$ coefficients estimated by regression on the basis of sample tree data. 
The secondary volume equations were used to calculate individual tree stem volume for all trees and to estimate total stand volume.

Heights of individual trees not actually measured were estimated as a function of their diameter using second-degree polynomial height curves. Height curves were then used to estimate top height using average values for the 100 trees with the largest diameter per hectare.

In the comparison of the exotic species and the native species, we used the two most productive Scots pine (SP) and lodgepole pine (LP) provenances at each site. The percentage increase or decrease in production resulting from using the exotic species instead of the native species was thus $100 \times($ SP-LP $) / L P$ for Canada and $100 \times($ LP_SP $) / S P$ for Sweden. We also compared the two best provenances of the exotic species with the local material of the native species (local lodgepole pine (LPL) in Canada and the provenance with the nearest origin in Sweden).

\section{Estimates of covariances among sites}

Data for block 5 at all sites were dropped prior to the linear mixed-model analysis. Variance and covariance estimates were generated according to the following linear mixed model:

$$
y=X \tau+Z_{\mathrm{g}} u_{\mathrm{g}}+Z_{\mathrm{p}} u_{\mathrm{p}}+e
$$

where $y$ is a vector of observations, $t$ is a vector of fixed effects, $u_{g}$ is a vector of random additive genetic effects, $u_{p}$ is a vector of random non-additive effects, $e$ is a vector of random residual effects, and $X, Z_{g}$ and $Z_{p}$ are incidence matrices for fixed, random additive genetic and random non-additive genetic effects, respectively. The fixed effects were composed of site, species, site-by-species interaction, provenance nested within species and the three-way interaction of site, species and provenance. The random effects $\left(u_{p}\right)$ were composed of family (GCA), cross (SCA), block nested within site and the interactions of site with family and cross. Random factors were assumed to have a multivariate normal distribution

$$
\left[\begin{array}{l}
u \\
e
\end{array}\right]=N\left(\left[\begin{array}{l}
0 \\
0
\end{array}\right],\left[\begin{array}{ll}
G & 0 \\
0 & R
\end{array}\right]\right),
$$

where $G$ is the (co)variance matrix for random effects $\left(u_{g}\right.$ and $\left.u_{p}\right)$ and $R$ is the (co)variance matrix for e. Restricted maximum likelihood (REML) analysis of the statistics software package ASReml-R (version 3) was used to estimate all variance and covariance components. Residuals for all traits were inspected visually and appeared to be normally distributed.

To estimate (co)variances among sites for $\mathrm{DBH}$, a multi-environment trial analysis was conducted for each species, using an approximate reduced animal model (ARAM) (Quaas \& Pollak 1980) in place of the full animal model. The ARAM is identical to the full animal model when there is no relatedness among parents. Using this model reduces computing time and memory usage (White et al. 2006). The additive genetic (co)variance among sites was estimated using a factor analytic model (Smith et al. 2001; Cullis et al. 2014) with three factors and the following $R$-matrix: 


$$
R=\left[\begin{array}{ccc}
\sigma_{e_{i q}}^{2} I_{n_{i q}} & 0 & 0 \\
0 & \ddots & 0 \\
0 & 0 & \sigma_{e_{j r}}^{2} I_{n_{j r}}
\end{array}\right],
$$

where $\sigma_{e_{\text {iqand }}}^{2} \sigma_{e_{\text {irare }}}^{2}$ the residual variances for sites $i$ and $j$, respectively; $I_{N}$ is an identity matrix of dimensions $N \times N(N=$ the number of trees); $q=1$ to $r$, and $r=$ the number of sites.

\section{Results}

\section{Species productivity}

On average for all sites in Canada, SP had larger DBH and higher survival (mortality due to mountain pine beetle not included) and volume (5.5\%, $28.4 \%$ and $22.4 \%$, respectively), but lower top height $(-10.4 \%)$ than LP, when all provenances were included (Table 3). SP had higher survival but lower top height than LP across all sites, while for volume and $\mathrm{DBH}$, the ranking of species varied. At the Renberget site (SWE-64), the exotic species (LP) had higher top height, survival and volume (11.3\%, $27.3 \%$ and $47.8 \%$, respectively), but lower diameter (-2.1\%) than the native species (SP). At Garsås (SWE-61), the species produced equally much and the production was much lower than at SWE-64. When data for both Swedish sites were combined, the superiority of top height and volume for LP was reduced by $50 \%$. The exotic species produced on average more than the native species in both Canada and Sweden, with the largest effect in Sweden, but the effect differed considerably between sites. The two best provenances of SP produced $34.6 \%$ and $13.7 \%$ more volume than the two best provenances of LP at CAN-56 and CAN-57, respectively, but $14.4 \%, 10.7 \%$ and $6.1 \%$ lower volume at the other three Canadian sites (Figure 2). At SWE-64, the two best LP provenances produced $43.1 \%$ more volume than the two best SP provenances. When comparing with the LPL seed-lot, the exotic SP also had higher production than the native in CAN-59. 


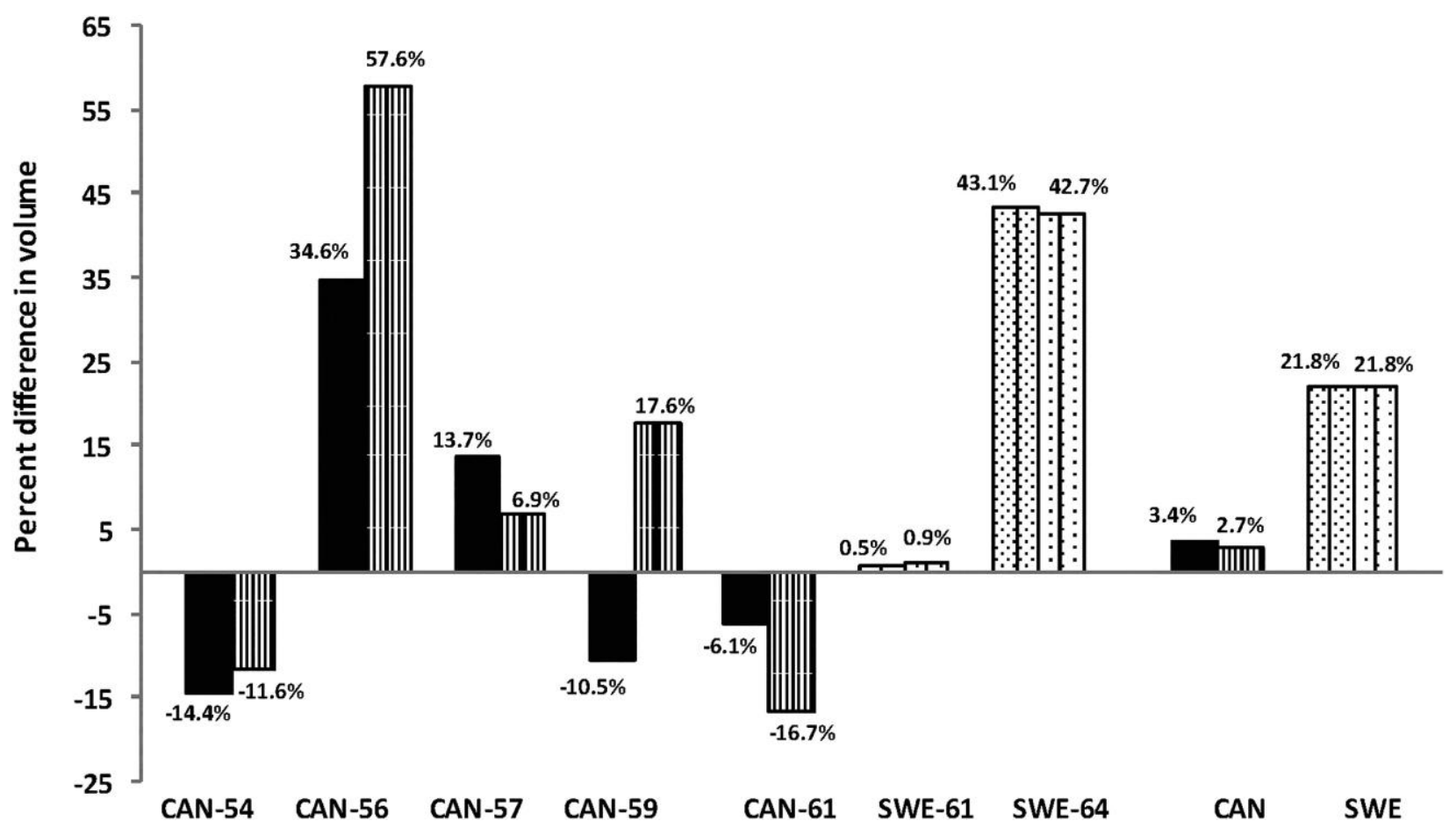

Figure 2. The percent differences in volume production of the two best seed-lots of the exotic species compared with the two best of the native species including the operational controls (left bar in each pair). The difference between the two best seed-lots of the exotic species and the local seedlot (right bar). 
Table 3. Stand data and difference between the exotic and native species based on data for all provenances at 25 years from planting. Averages for each species (LP = lodgepole pine; SP = Scots pine) and difference between the exotic and native species.

\begin{tabular}{|c|c|c|c|c|c|c|c|c|c|c|c|c|}
\hline \multirow[b]{2}{*}{8.5} & \multicolumn{3}{|c|}{$\mathrm{DBH}$ over bark ${ }^{\mathrm{a}}(\mathrm{mm})$} & \multicolumn{3}{|c|}{ Top height $(\mathrm{m})$} & \multicolumn{3}{|c|}{ Survival $^{\mathrm{b}}(\%)$} & \multicolumn{3}{|c|}{ VOL $\left(m^{3} h a^{-1}\right)$} \\
\hline & LP & SP & $\begin{array}{c}\text { Exotic } \\
\text { vs. } \\
\text { native } \\
\text { species } \\
(\%)^{c}\end{array}$ & LP & $\mathrm{SP}$ & $\begin{array}{c}\text { Exotic } \\
\text { vs. } \\
\text { native } \\
\text { species } \\
(\%)^{c}\end{array}$ & LP & $\mathrm{SP}$ & $\begin{array}{c}\text { Exotic } \\
\text { vs. } \\
\text { native } \\
\text { species } \\
(\%)^{c}\end{array}$ & LP & SP & $\begin{array}{c}\text { Exotic } \\
\text { vs. } \\
\text { native } \\
\text { species } \\
(\%)^{c}\end{array}$ \\
\hline CAN-54 & 163 & 170 & 4.3 & 10.7 & 9.0 & -15.9 & 93 & 96 & 3.2 & 141 & 126 & -10.6 \\
\hline CAN-56 & 136 & 134 & -1.5 & 8.7 & 8.0 & -8.0 & 58 & 93 & 60.3 & 44 & 66 & 50.0 \\
\hline CAN-57 & 158 & 182 & 15.2 & 10.4 & 9.5 & -8.7 & 68 & 91 & 33.8 & 70 & 130 & 85.7 \\
\hline CAN-59 & 172 & 191 & 11.0 & 11.8 & 10.1 & -14.4 & 68 & 88 & 29.4 & 102 & 120 & 17.6 \\
\hline CAN-61 & 98 & 89 & -9.2 & 6.6 & 6.2 & -6.1 & 59 & 75 & 27.1 & 12 & 10 & -16.7 \\
\hline \multirow[t]{2}{*}{$\begin{array}{l}\text { Average } \\
\text { CAN }\end{array}$} & 145 & 153 & 5.5 & 9.6 & 8.6 & -10.4 & 69.1 & 88.7 & 28.4 & 73.7 & 90.2 & 22.4 \\
\hline & LP & $\mathrm{SP}$ & $\begin{array}{c}\text { Exotic } \\
\text { vs. } \\
\text { native } \\
\text { species } \\
(\%)^{d}\end{array}$ & LP & $\mathrm{SP}$ & $\begin{array}{c}\text { Exotic } \\
\text { vs. } \\
\text { native } \\
\text { species } \\
(\%)^{d}\end{array}$ & LP & $\mathrm{SP}$ & $\begin{array}{l}\text { Exotic } \\
\text { vs. } \\
\text { native } \\
\text { species } \\
(\%)^{d}\end{array}$ & LP & SP & $\begin{array}{l}\text { Exotic } \\
\text { vs. } \\
\text { native } \\
\text { species } \\
(\%)^{d}\end{array}$ \\
\hline SWE-61 & 170 & 173 & -1.7 & 11.4 & 11.5 & -0.9 & & & & 99 & 102 & -2.9 \\
\hline SWE-64 & 183 & 187 & -2.1 & 12.8 & 11.5 & 11.3 & 84 & 66 & 27.3 & 170 & 115 & 47.8 \\
\hline $\begin{array}{l}\text { Average } \\
\text { SWE }\end{array}$ & 176 & 180 & -2.0 & 12.1 & 11.5 & 5.2 & 67 & 62 & 8.1 & 135 & 108 & 24.2 \\
\hline $\begin{array}{l}\text { Weighted } \\
\text { average } \\
\text { CAN+SWE }\end{array}$ & 154 & 161 & & 10.3 & 9.4 & & 68.5 & 81.1 & & 91.1 & 95.4 & \\
\hline
\end{tabular}

${ }^{a} \mathrm{DBH}$ is the average DBH of the 100 tallest trees per hectare (trees with heights estimated by diameter included), that is, top height; VOL is volume production per hectare.

${ }^{\mathrm{b}}$ Trees recently killed by mountain pine beetle were included among living trees (see materials and methods).

'Species difference based on all provenances in Canada, (SP-LP)/LP (\%).

${ }^{d}$ Species difference based on all provenances in Sweden, (LP-SP)/SP (\%).

At the SWE-64 site, LP produced $229 \mathrm{~m}^{3} \mathrm{ha}^{-1}$ and SP $110 \mathrm{~m}^{3} \mathrm{ha}^{-1}$ (108\% higher production for LP) when planted in the block where the species, provenances and families were mixed (block 5), while in the uniform 64-tree plots (blocks 1-4), the corresponding volumes were $173 \mathrm{~m}^{3} \mathrm{ha}^{-1}$ for LP and 118 $\mathrm{m}^{3} \mathrm{ha}^{-1}$ for SP (47\% higher production) (data not shown). 


\section{Provenance variation}

Among the LP provenances planted in Canada (excluding local seed-lots, LPL), LP57 had the highest volume at all sites, and its relative volume production compared with LPL ranged from $-26 \%$ to $+25 \%$ (Table 4). LPL had the highest production in two sites (CAN-57 and CAN-59) and 4-20\% lower than the top provenance in the other three. The SP provenance from $63^{\circ}$ latitude (SP63) had the highest volume production of all provenance materials at the three northern sites in Canada, where its relative volume production compared with LPL ranged from $-20 \%$ to $+42 \%$. The top SP provenance at site CAN-54 was SP59 ( $-11 \%$ compared to LPL), while at CAN-56 SP61 performed best (+59\%). In Sweden, the LP provenance with the most southern origin (LP55) had the highest volume at both sites. For SP, SP63 had the highest volume at the southern Swedish site (SWE-61) and SP65 the highest volume at the northern site (SWE-64). At CAN-59, heavy snowfall caused considerable stem damage in the spring of the year of measurement. The LPL operational control seed-lot (LPL), which had the highest volume, had less damage than transferred LP provenances, but the least damage occurred on SP (Table 5).

\section{Genetic correlations among sites}

Type B genetic correlations (genetic correlations among sites) were calculated for DBH. For LP in Canada, the four southern sites had rather high correlations, which increased with decreasing distance between the sites (from 0.69 to 0.99) (Table 6; Figure 3). CAN-61 was poorly correlated with the southernmost Canadian site (CAN-54), but also here the correlation increased with decreasing difference in latitude (from 0.24 to 0.70). There was no correlation between CAN-61 and the Swedish sites. Growth of LP in the two Swedish sites was highly correlated (0.82) and it was relatively highly correlated with the two southern Canadian sites. For SP, the four southern Canadian sites were all highly correlated. CAN-61 had very low correlations with the four southern Canadian sites and SWE61, but rather high correlation with SWE-64. The two Swedish sites were highly correlated with each other (0.96). SP in the Swedish sites showed similar correlations with the four southern Canadian sites, but with generally lower correlations for SWE-64 than for SWE-61. 
Table 4. Volume production $\left(\mathrm{m}^{3} \mathrm{ha}^{-1}\right)$ of different provenances of LP and SP in blocks 1-4 at indicated test sites in Canada (CAN) and Sweden (SWE).

\begin{tabular}{|c|c|c|c|c|c|c|c|c|c|}
\hline Provenance & $\begin{array}{c}\text { CAN- } \\
54\end{array}$ & $\begin{array}{c}\text { CAN- } \\
56\end{array}$ & $\begin{array}{c}\text { CAN- } \\
57\end{array}$ & $\begin{array}{c}\text { CAN- } \\
59\end{array}$ & $\begin{array}{c}\text { CAN- } \\
61\end{array}$ & CAN & $\begin{array}{c}\text { SWE- } \\
61\end{array}$ & $\begin{array}{c}\text { SWE- } \\
64\end{array}$ & SWE \\
\hline LP55 & $\begin{array}{l}154 \\
\text { (2) } a\end{array}$ & $\begin{array}{c}52 \\
(18) \\
b c d\end{array}$ & $\begin{array}{c}85 \\
(-35) \\
b c\end{array}$ & & $\begin{array}{c}8 \\
(-33)\end{array}$ & & 133 & $194 a$ & \\
\hline LP57 & $\begin{array}{l}157 \\
\text { (4) } a\end{array}$ & $\begin{array}{c}52 \\
(18) \\
c d\end{array}$ & $\begin{array}{c}115 \\
(-12) \\
a b\end{array}$ & $\begin{array}{c}141 \\
(-26) \\
a b c\end{array}$ & $\begin{array}{c}15 \\
(25)\end{array}$ & & 94 & $\begin{array}{c}177 \\
a b\end{array}$ & \\
\hline LP59 & $\begin{array}{c}101 \\
(-33) \\
d\end{array}$ & $\begin{array}{c}26 \\
(-41) \\
e\end{array}$ & $\begin{array}{c}69 \\
(-47) \\
b c\end{array}$ & $\begin{array}{c}124 \\
(-35) \\
b c d\end{array}$ & $\begin{array}{c}15 \\
(25)\end{array}$ & & 80 & $\begin{array}{c}176 \\
a b\end{array}$ & \\
\hline LP61 & & & $\begin{array}{c}20 \\
(-85) \\
d\end{array}$ & $\begin{array}{c}33 \\
(-83) \\
e\end{array}$ & $\begin{array}{c}11 \\
(-8)\end{array}$ & & 76 & $\begin{array}{l}171 \\
a b c\end{array}$ & \\
\hline LP63 & & & $\begin{array}{c}5 \\
(-96) \\
d\end{array}$ & $\begin{array}{c}22 \\
(-88) \\
e\end{array}$ & $\begin{array}{c}10 \\
(-10)\end{array}$ & & & $\begin{array}{c}134 \\
a b c d\end{array}$ & \\
\hline LPL & $151 a b$ & $44 d$ & $130 a$ & $191 a$ & 12 & & & & \\
\hline SP55 & $\begin{array}{c}121 \\
(-20) \\
c d\end{array}$ & & & & & & 82 & & \\
\hline SP57 & $\begin{array}{c}132 \\
(-13) \\
a b c\end{array}$ & $\begin{array}{c}66 \\
(50) \\
a b c\end{array}$ & $\begin{array}{c}122 \\
(-6) a\end{array}$ & & & & 87 & & \\
\hline SP59 & $\begin{array}{c}135 \\
(-11) \\
a b c\end{array}$ & $\begin{array}{c}69 \\
(57) \\
a b\end{array}$ & $\begin{array}{c}138 \\
\text { (6) } a\end{array}$ & $\begin{array}{c}140 \\
(-27) \\
a b c\end{array}$ & $\begin{array}{c}6 \\
(-50)\end{array}$ & & 100 & & \\
\hline SP61 & & $\begin{array}{c}70 \\
\text { (59) } a\end{array}$ & $\begin{array}{l}132 \\
(2) a\end{array}$ & $\begin{array}{c}144 \\
(-25) \\
a b\end{array}$ & & & & $89 d$ & \\
\hline SP63 & $\begin{array}{c}125 \\
(-17) \\
b c d\end{array}$ & $\begin{array}{c}65 \\
(48) \\
a b c\end{array}$ & $\begin{array}{l}140 \\
\text { (8) } a\end{array}$ & $\begin{array}{c}152 \\
(-20) \\
a b\end{array}$ & $\begin{array}{c}17 \\
(42)\end{array}$ & & 125 & $\begin{array}{l}123 \\
b c d\end{array}$ & \\
\hline
\end{tabular}




\begin{tabular}{|c|c|c|c|c|c|c|c|c|c|}
\hline Table 4, cd. & & & & & & & & & \\
\hline Provenance & $\begin{array}{c}\text { CAN- } \\
54\end{array}$ & $\begin{array}{l}\text { CAN- } \\
56\end{array}$ & $\begin{array}{l}\text { CAN- } \\
57\end{array}$ & $\begin{array}{l}\text { CAN- } \\
59\end{array}$ & $\begin{array}{c}\text { CAN- } \\
61\end{array}$ & CAN & $\begin{array}{c}\text { SWE- } \\
61\end{array}$ & $\begin{array}{c}\text { SWE- } \\
64\end{array}$ & SWE \\
\hline SP65 & $\begin{array}{c}116 \\
(-23) \\
c d\end{array}$ & $\begin{array}{c}59 \\
(34) \\
a b c d\end{array}$ & $\begin{array}{c}116 \\
(-11) \\
a b\end{array}$ & $\begin{array}{c}120 \\
(-37) \\
b c d\end{array}$ & $\begin{array}{c}9 \\
(-25)\end{array}$ & & 94 & $\begin{array}{l}137 \\
a b c d\end{array}$ & \\
\hline SP66 & & & & $\begin{array}{c}88 \\
(-54) \\
c d\end{array}$ & $\begin{array}{l}11 \\
(-8)\end{array}$ & & & $\begin{array}{c}105 \\
c d\end{array}$ & \\
\hline SP67 & & & & $\begin{array}{c}75 \\
(-61) \\
d e\end{array}$ & $\begin{array}{c}8 \\
(-33)\end{array}$ & & & $\begin{array}{l}121 \\
b c d\end{array}$ & \\
\hline $\begin{array}{l}\text { Mean (excl. } \\
\text { LPL) LP }\end{array}$ & $\begin{array}{c}137.5 \\
(-9)\end{array}$ & $\begin{array}{l}58.4 \\
(33)\end{array}$ & $\begin{array}{l}43.3 \\
(-67)\end{array}$ & $\begin{array}{l}79.7 \\
(-58)\end{array}$ & $\begin{array}{l}11.8 \\
(-2)\end{array}$ & & 95.5 & 170.3 & \\
\hline $\begin{array}{l}\text { Mean (incl. } \\
\text { LPL) LP }\end{array}$ & 140.8 & 43.5 & 70.7 & 102.2 & 11.8 & & 95.5 & 170.3 & \\
\hline SP & $\begin{array}{l}125.9 \\
(-17)\end{array}$ & $\begin{array}{l}65.9 \\
(50)\end{array}$ & $\begin{array}{c}129.6 \\
(0)\end{array}$ & $\begin{array}{l}119.9 \\
(-37)\end{array}$ & $\begin{array}{c}10.1 \\
(-16)\end{array}$ & & 97.5 & 114.8 & \\
\hline $\begin{array}{l}\text { Two best } \\
\text { (incl. LPL) LP }\end{array}$ & 155.6 & 52.0 & 122.2 & 165.7 & 14.7 & 102.4 & 113.0 & 185.4 & 149.2 \\
\hline Two best SP & $\begin{array}{l}133.2 \\
(-12)\end{array}$ & $\begin{array}{l}70.0 \\
(59)\end{array}$ & $\begin{array}{c}139.0 \\
(6)\end{array}$ & $\begin{array}{l}148.0 \\
(-23)\end{array}$ & $\begin{array}{l}13.8 \\
(15)\end{array}$ & 100.8 & 112.4 & 129.6 & 121 \\
\hline
\end{tabular}

Notes: Figures followed by different letters are significantly different and numbers within brackets are percent differences from the LP operational control seed-lots (LPL). For the CAN-61 and SWE-61 test sites, no differences were significant.

Table 5. Stem damage for LP, the local operational seed-lot (LPL) and SP at Fort Nelson (CAN-59).

\begin{tabular}{||c||c|c|c||}
\hline Provenance & Percent broken stem & Percent toppled & Sum \\
\hline \hline LP57 - LP63 & 16.3 & 9.3 & 25.5 \\
\hline \hline LPL & 2.9 & 7.0 & 9.9 \\
\hline \hline SP59 - SP67 & 1.4 & 3.2 & 5.9 \\
\hline
\end{tabular}




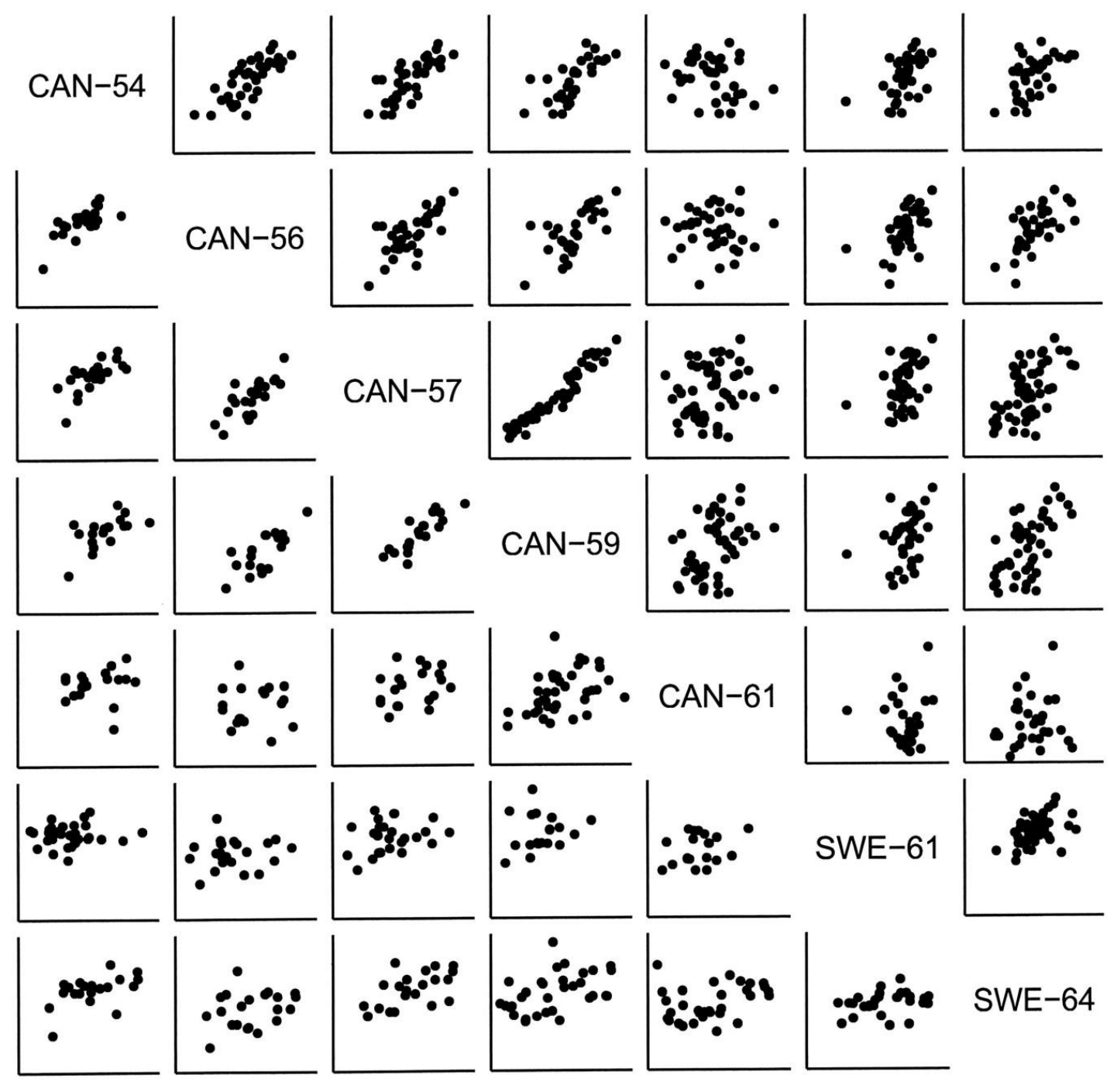

Figure 3. Scatterplots for genetic correlations between sites for DBH of LP (above diagonal) and SP (below diagonal). The $x$ - and $y$-axes indicate DBH of the seed-lots in the sites each plot refers to. 
Table 6. Genetic correlations between sites (type B genetic correlations) for DBH of LP (above diagonal) and SP (below diagonal).

\begin{tabular}{||c||c|c|c|c|c|c||c||}
\hline & CAN-54 & CAN-56 & CAN-57 & CAN-59 & CAN-61 & SWE-61 & SWE-64 \\
\hline \hline CAN-54 & & 0.93 & 0.76 & 0.69 & 0.24 & 0.96 & 0.77 \\
\hline \hline CAN-56 & 0.90 & & 0.94 & 0.90 & 0.47 & 0.86 & 0.68 \\
\hline \hline CAN-57 & 0.91 & 0.84 & & 0.99 & 0.66 & 0.63 & 0.47 \\
\hline \hline CAN-59 & 0.72 & 0.74 & 0.94 & & 0.70 & 0.55 & 0.40 \\
\hline \hline CAN-61 & 0.11 & -0.28 & 0.25 & 0.21 & & 0.09 & 0.03 \\
\hline \hline SWE-61 & 0.86 & 0.60 & 0.90 & 0.76 & 0.59 & & 0.82 \\
\hline \hline SWE-64 & 0.72 & 0.36 & 0.74 & 0.57 & 0.77 & 0.96 & \\
\hline
\end{tabular}

\section{Discussion}

\section{Exotic vs. native species}

Based on the two best producing seed-lots, the exotic species (LP) had higher production than the native SP in one of the Swedish sites (SWE-64), while it was equal in the other (SWE-61) (Table 4; Figure 2). SWE-61 was, however, severely damaged by pine weevil, which caused a high mortality at an early age. At the latitude of SWE-61, the expected survival of local material of SP is ca $68 \%$ (Eriksson et al. 1980). The low survival in this site and comparatively slow height growth in our inventory, only $45 \%$ of the plots had more than 20 of 64 surviving trees, are quite exceptional. In 44 replicated Swedish experiments with both species examined by Elfving and Norgren (1993), LP survived better in most experiments and grew faster in 43 of them. The considerably higher production of LP compared to SP at SWE-64 may, however, be a result of the release of Canadian pathogens, but contributing factors could be a higher growth capacity and that the Swedish soil has shown to provide better biota for LP than the Canadian soil (Gundale et al. 2014) and that the Swedish soil has lower net nitrogen immobilization than soils in Canadian LP stands (Mclntosh et al. 2012).

In Canada the sites CAN-54 and CAN-56 were attacked by mountain pine beetle prior to measurements, and SP was considerably more damaged than LP (53\% compared to $21 \%$ and $95 \%$ compared to $53 \%$ in CAN-54 and CAN-56, respectively). The trees killed by mountain pine beetle were included when production was calculated and their potential growth 1-3 years prior to measurements was thus not included. Therefore, their estimated productivity was somewhat underestimated and since SP was more frequently killed by mountain pine beetle, calculated production in those sites became more reduced for SP than for LP. Based on the two best seed-lots of each species, exotic SP produced more than the native LP in two sites (CAN-56 and CAN-57), 
while LP grew better in three. Based on all seed-lots, the exotic SP had higher production at CAN-59 and on average produced more than LP. LP had higher top height in Canada (Table 3), which indicated higher production potential, but the higher production potential is not obvious here and one reason could be the more damage it suffers, which thereby reduces its growth. Thus, the simultaneous inventory of diseases showed that in Canada all pathogen species occurring on LP except western gall rust were missing or occurred only in single infections on SP (Fries unpublished data). The same situation could sometimes occur for LP in Sweden: its superiority in production in SWE-64 and often in Sweden (Elfving \& Norgren 1993) could be because the native SP is more severely affected by pests and pathogens occurring in Sweden. We suggest thus that the result in some sites in the present study may follow the "enemy release hypothesis" described in Mitchell and Power (2003) and Mitchell et al. (2006). The higher production of LP than SP at three of the Canadian sites shows, however, that it is possible to find native well-adapted materials with high production.

The much larger mortality among SP due to mountain pine beetle in two Canadian sites demonstrates the risks with species introduction. Furthermore, in general the risk with disease or insect attack may in future increase due to adaptation of the disease or insect to also attack the exotic species (Karlman 2001; Garbelotto \& Pautasso 2012). A similar example to mountain pine beetle is attacks by Gremmeniella abietina on LP in parts of northern Sweden. After severe snow conditions in the winter 1993/94, infection of Gremmeniella was very frequent and caused high mortality on LP, while SP suffered much less (Hansson \& Karlman 1997). On the other hand, in the same study snow blight (Phacidium infestans) infected the native SP to a considerably higher degree than LP. These opposite results for LP demonstrate not only the potential risks, but also possibilities with introduced species.

Block five, with mixed species and provenances, was only measured at SWE-64. In this site monocultural blocks with LP produced $47 \%$ more than those with SP. In block five the volume of LP was $108 \%$ larger than that of SP. This indicates that when planted together, LP will have a significant competitive advantage over SP.

\section{Provenance variation}

The climate in northern Sweden has a substantial maritime influence originating from the west from the Gulf Stream of the Atlantic Ocean west of Norway and, to a minor extent, from the Gulf of Bothnia to the east. In Sweden, LP is therefore planted in sites with a less continental climate than east of the Coastal Mountains in Canada from where much of the LP is taken. Further south in British Columbia, the climate is milder. Provenances from these areas had higher volume production in the site in north Sweden (SWE-64) than provenances from more northern latitudes. This indicates that climatic similarities, rather than latitude or elevation, are more suitable for matching provenances in Canada with breeding zones in Sweden (cf. Kreyling et al. 2015). This is also consistent with recommendations in Sweden for the selection of LP provenances (http://www.kunskapdirekt.se /sv/KunskapDirekt/Alla-Verktyg/Planters-guide-2/ [July 2016]).

British Columbia has considerable environmental and climatic variation (Pojar et al. 1987), which according to Mátyás (1996) result in steep genetic clines for the native species. Large geographic transfers often result in a high degree of stress and increased susceptibility to damage, pests and pathogens (Karlman 2001; La Porta et al. 2008). This has resulted in large population-level variation for LP, with specialized adaptation to local biotic and abiotic factors, and maladaptation is probably a reason for the greater snow damage on the non-local lodgepole pine than on the local seed-lot at 
CAN-59 (Table 5). This highlights the importance of local adaptation of the species in Canada. Nevertheless, SP seems to be even better adapted to heavy snow (Table 5), a trait that has probably evolved under the maritime climate in Sweden. The larger needle biomass of LP compared to SP making it more sensitive to snow and wind may, thus, reduce the potentially higher productivity of LP. Furthermore, the different SP provenances show similar relationships to the LPL at the different sites, indicating that the species has higher phenotypic stability over environmental gradients than LP.

In regions with significant environmental heterogeneity, a policy to use local seed-lots for reforestation will exploit local adaptation to minimize the risk of damage by biotic and abiotic factors, but may not allow the optimization of volume production. However, with adequate information from well-designed provenance tests and multispecies trials, it should be possible to optimize volume production through species and population selection. In the current study, at three sites in Canada, CAN-56, CAN-57 and CAN-61, the best performing seed-lot was a SP seed-lot. Their average gain in volume over the local seed-lots (LPL) was 36\% (Table 4). At one site (CAN-54), the best performing seed-lot was a transferred LP provenance with a volume gain of $4 \%$, and at one site (CAN-59), the local seed-lot had the highest volume production of all LP and SP seed-lots (26\% higher production than the second best). Furthermore, the use of the optimum LP seed-lot instead of the local operational seed-lot (LPL) would have resulted in an average gain in volume of $9.4 \%$. This agrees with modeling with LP by Wang et al. (2006b), suggesting that seed-lot selection can be used to mitigate the negative impacts of climate change and optimize volume production in LP; it was reported that an increase in volume of $14-36 \%$ can be achieved with seed-lot selection and moderate levels of climate change. In addition, our data show that if SP seed-lots are included for selection, the potential gain could be $23 \%$.

These results after 25 years are of course only indicative. Final conclusions cannot be drawn before optimum rotation age, which can vary between 70 and 100 years for the different sites and species in the study. The heavy attack by mountain pine beetle has destroyed a meaningful continuation of this experiment and demonstrates the difficulties to evaluate forest productivity by long-term field experiments. Long-term evaluation of productivity must be based on growth modeling.

\section{Correlations between sites and phenotypic stability}

Given the pattern of the genetic correlations between sites (type B genetic correlations) for LP in northwestern Canada (Table 6), there is a need for multiple breeding zones in Yukon and Canada. The northernmost zone should be the Whitehorse area (CAN-61). The clinal increase in correlation with decreasing distance between the other four sites did, on the other hand, not indicate any clear boundary, with the possible exception of a boundary between the Mackenzie and Fort St John area (CAN-56 and CAN-57). The more stable type B genetic correlations for SP than LP between Canadian and Swedish sites indicated that SP is less affected by changes in the climatic, biotic and abiotic factors across northern British Columbia. Seven out of 10 correlations between the Canadian and Swedish sites were 0.60 or higher and with a total variation of between 0.36 and 0.90 for SP, while 5 out of 10 correlations for LP in Sweden were 0.60 or higher (total variation $0.03-0.96$ ). This suggests a higher degree of phenotypic stability of SP than of LP, which may be the result of adaptation to lower variation in the biotic environments in Sweden (Mátyás 1996) than in western Canada. CAN-54 was the site in Canada with the highest type B genetic correlation with SWE-64 for LP. This indicates that there are similarities between southern locations in western Canada and regions in northern Sweden. Thus, selection results from the CAN-54 site and the CAN-56 site are most appropriate for supporting the LP breeding program in northern Sweden. 


\section{Conclusions}

One goal of this transcontinental reciprocal transplant experiment was to compare the overall productivity of LP and SP in their native and exotic environments. In some sites, the introduced species (LP in Sweden and SP in Canada) provided higher volume production than the native species, but in others the native species produced more. The higher production of LP than SP in one Swedish site, and frequently in Swedish forestry, may be due to its higher production capacity but contributing is probably that damage by pathogens and insects are fewer, thus in accordance with the so-called enemy release theory. Also, the Swedish soil seems to provide better biota and nitrogen availability for LP than the Canadian soil.

Despite higher production of the exotic SP than LP in some sites in western Canada, there are many LP populations that can be utilized to maximize productivity on managed forest lands. Good performance of the less continental southern provenances of LP in the Swedish sites demonstrates that climatic similarities, rather than latitude or elevation, should be used for matching provenances in Canada with breeding zones in Sweden. High correlation between Canadian and Swedish sites for SP indicates its relatively high phenotypic stability. More severe damage by mountain pine beetle on SP than on LP in Canada, together with previous outbreaks of Gremmeniella on LP in Sweden, indicates, however, risks with species introductions.

\section{Funding}

This work was supported by the Bo Rydin Foundation, Sweden, [grant number F06/09].

\section{Acknowledgements}

The experiment was initiated by the late Professor and Chief Silviculturalist at SCA, Stig Hagner, and inspired by the Professor in forest pathology at Swedish University of Agricultural Sciences, Margareta Karlman, together with the late Professor Oscar Sziklai at University of British Columbia, Canada. Many people have supported and contributed to the experiment: Michael Carlson, Bart Van der Kamp, Dag Lindgren, Per Persson and at Balco Forest Industries Ltd, Christian Walli. The latter company, together with Canadian Forest Products Ltd, TimberWest Forest Ltd and Future Forest Ltd in Canada, offered much support for the work in Canada. We acknowledge all those forces that enabled the study. The authors also thank Charlie Cartwright and Chang-Yi Xie for their thorough reviews and Per Hansson for important comments.

\section{Disclosure statement}

No potential conflict of interest was reported by the authors. 


\section{References}

Andersson S-O. 1954. Funktioner och tabeller för kubering av småträd. [Empirical formulae and tables for determining the volume of small trees]. Medd Stat Skogsforskningsinst. 44:1-29. Swedish with German summary.

Brandel G. 1990. Volymfunktioner for enskilda träd. Tall, gran och björk. [Volume functions for individual trees; Scots pine (Pinus sylvestris), Norway spruce (Picea abies) and birch (Betula pendula \& Betula pubescens)], Report 26:1-183. Swedish University of Agricultural Sciences, Deptartment of Forest Yield Research. Swedish with English summary.

Cubbage F, Donagh PM, Balmelli G, Olmos VM, Bussoni A, Rubilar R, de la Torre R, Lord R, Huang J, Hoeflich VA, et al. 2014. Global timber investments and trends, 2005-2011. Conf. proceedings, planted forests on the globe - renewable resources for the future. Proceedings of the Third International Congress on Planted Forests, Bordeaux, France; Dublin, Ireland; and Porto and Estoril, Portugal; 2013 May 16-21. Ed. R. Falshaw. New Zeal J For Sci. 44:suppl. 1. 12p.

Cullis BR, Jefferson P, Thompson R, Smith AB. 2014. Factor analytic and reduced animal models for the investigation of additive genotype-by-environment interaction in outcrossing plant species with application to a Pinus radiata breeding programme. Theor Appl Genet. 127:2193-2210.

Elfving B, Ericsson T, Rosvall O. 2001. The introduction of lodgepole pine for wood production in Sweden - a review. For Ecol Manage. 141:15-29.

Elfving B, Norgren O. 1993. Volume yield superiority of lodgepole pine compared to Scots pine in Sweden. In: Lindgren D, editor. Pinus contorta - From untamed forest to domesticated crop.

Proceedings of a meeting with IUFRO WP 2.02.06 and Frans Kempe Symposium; 1992 Aug 24-28; Department of Forest Genetics and Plant Physiology, Swedish University of Agricultural Sciences, Report 11:69-80.

Eriksson H. 1973. Tree volume functions for ash, aspen, alder and lodgepole pine in Sweden. Royal College of Forestry, Department of Forest Yield Research. Research Notes 26:1-26. Swedish with English summary.

Eriksson G, Andersson S, Eiche V, Ifver J, Persson A. 1980. Severery index and transfer effects on survival and volume production of Pinus sylvestris in northern Sweden. Stud For Suec. 156:1-32.

Garbelotto M, Pautasso M. 2012. Impacts of exotic forest pathogens on Mediterranean ecosystems: four case studies. Eur J Plant Pathol. 133:101-116.

Gundale MJ, Kardol P, Nilsson M-C, Nilsson U, Lucas RW, Wardle DA. 2014. Interactions with soil biota shift from negative to positive when a tree species is moved outside its native range. New Phytol. 202:415-421. 
Hansson P, Karlman M. 1997. Survival, height and health status of 20-year-old Pinus sylvestris and Pinus contorta after different scarification treatments in a harsh boreal climate. Scand J For Res. 12:340-350.

A Joint Swedish - Canadian. 1987. A joint Swedish-Canadian Forest Industry-university project. A species-genotype-environment-interaction study. The Swedish University of Agricultural Sciences, The Faculty of Forestry, Umeå, Sweden. 2p.

Karlman M. 1981. The introduction of exotic tree species with special reference to Pinus contorta in northern Sweden. Stud For Suec. 158:1-25.

Karlman M. 1986. Damage to Pinus contorta in northern Sweden with special emphasis on pathogens. Stud For Suec. 176:1-42.

Karlman M. 2001. Risks associated with the introduction of Pinus contorta in northern Sweden with respect to pathogens. For Ecol Manage. 141:97-105.

Karlman M, Van der Kamp B, Witzell J. 1997. Susceptibility of Pinus sylvestris to stem rusts of Pinus contorta in Western Canada. Scand J For Res. 12:168-178.

Keane RM, Crawley MJ. 2002. Exotic plant invasions and the enemy release hypothesis. Trends Ecol Evol. 17:164-170.

Kreyling J, Schmid S, Aas G. 2015. Cold tolerance of tree species is related to the climate of their native ranges. J Biogeography. 42:156-166.

La Porta N, Capretti P, Thomsen IM, Kasanen R, Hietala AM, Von Weissenberg K. 2008. Forest pathogens with higher damage potential due to climate change in Europe. Can J Plant Pathol. 30:177-195.

Lindgren D, Lindgren K. 1990. A Canadian-Swedish species-genotype environment interaction study. In: Douglas-fir, Contorta Pine, Sitka Spruce and Abies Breeding and Genetic Resources.

Proceedings of a joint meeting with IUFRO WP S2.02-05, 06, 12 and 14. 1990 Aug 20-24; Western Forest Genetics Association, Olympia, Washington; 10p.

Lindgren K, Lindgren D, Rosvall O. 1988. Förflyttningsrekommendation för provenienser av contortatall i Sverige, Working paper 27:1-43. Swedish: Swedish University of Agricultural Sciences, Department of Forest Genetics and Plant Physiology.

Mátyás C. 1996. Climatic adaptation of trees: rediscovering provenance tests. Euphytica. 92:45-54. 
McIntosh ACS, Macdonald SE, Gundale MJ. 2012. Tree species versus regional controls on ecosystem properties and processes: an example using introduced Pinus contorta in Swedish boreal forests. Can J For Res. 42:1228-1238.

Mitchell CE, Agrawal AA, Bever JD, Gilbert GS, Hufbauer RA, Klironomos JN, Maron JL, Morris WF, Parker IM, Power AG, et al. 2006. Biotic interactions and plant invasions. Ecol Lett. 9:726-740.

Mitchell CE, Power AG. 2003. Release of invasive plants from fungal and viral pathogens. Nature. $421: 625-627$.

Norgren O. 1996. Growth analysis of Scots pine and lodgepole pine seedlings. For Ecol Manage. 86:15-26.

Piirto DD, Valkonen S. 2005. Structure and development of pitch canker infected Monterey pine stands at Año Nuevo, California. For Ecol Manage. 213:160-174.

Pojar J, Klinka K, Meidinger DV. 1987. Biogeoclimatic ecosystem classification in British Columbia. For Ecol Manage. 22:119-154.

Quaas RL, Pollak EJ. 1980. Mixed model methodology for farm and ranch beef cattle testing programs. J Animal Sci. 51:1277-1287.

Rosvall O, Andersson B, Ericsson T. 1998. Beslutsunderlag för val av skogsodlingsmaterial i norra Sverige med trädslagsvisa guider. [Species-specific guidelines for choosing forest regeneration material for northern Sweden]. Skogforsk Redogörelse nr 1:1-66. Swedish with English summary.

Skogsstyrelsen. 2013. Skogsstatistisk årsbok. [Swedish statistical yearbook of forestry]. Skogsstyrelsen: Jönköping, Sweden: 1-376. Swedish with English summary.

Smith A, Cullis B, Thompson R. 2001. Analyzing variety by environment data using multiplicative mixed models and adjustments for spatial field trend. Biometrics. 57:1138-1147.

Tigerstedt PMA. 1993. Why do exotic trees often exceed the yield of endemic trees. In: Lindgren D, editor. Pinus contorta - From untamed forest to domesticated crop. Proceedings of a meeting with IUFRO WP 2.02.06 and Frans Kempe Symposium. 1992 Aug 24-28; Department of Forest Genetics and Plant Physiology, Swedish University of Agricultural Sciences, Report 11:60-68.

Van der Kamp BJ, Karlman M, Witzell J. 1995. Relative frequency of bole and branch infection of lodgepole pine by western gall rust. Can J For Res. 25:1962-1968. 
Verhaegen D, Randrianjafy $\mathrm{H}$, Rakotondraoelina Andriatsitohaina $\mathrm{H}$, Trendelenburg Rakotonirina $\mathrm{M}$ C, Andriamampianina N, Montagne P, Rasamindisa A, Chaix G, Bouillet J-P, Bouvet J-M. 2014. Eucalyptus robusta pour une production durable de bois énergie à Madagascar: bilan des connaissances et perspectives. Bois et Forêts de Tropiques 320,16p. French with English summary.

Wang B, D'Eon S, Dong J. 2006a. Introduction of Canadian tree species to the Northeast of China. For Chron. 82:219-225.

Wang T, Hamann A, Yanchuk A, O'Neill GA, Aitken SN. 2006b. Use of response functions in selecting lodgepole pine populations for future climates. Glob Change Biol. 12:2404-2416.

White IMS, Roehe R, Knap PW, Brotherstone S. 2006. Variance components for survival of piglets at farrowing using a reduced animal model. Genet Sel Evol. 38:359-370. 